\title{
PENGARUH IKLIM ORGANISASI TERHADAP PRODUKTIVITAS KERJA PEGAWAI PADA DINAS PERHUBUNGAN KOTA TANGERANG
}

\author{
Ditulis Oleh: Silvia Sumantri ${ }^{1}$, H. Achmad Murodi, Drs., MM² , H. Refly Badar, Drs. M.Si ${ }^{3}$ \\ Dosen Tetap Yayasan Prodi Ilmu Administrasi Negara FISIP - UNIS Tangerang
}

\begin{abstract}
ABSTRAK
Populasi pada penelitian ini berjumlah 109 orang, sedangkan untuk mengtahui jumlah sampel yang akan dijadikan reponden diambil berdasarkan rumus slovin dengan sampel 86 orang. Dalam penelitian ini metode yang digunakan adalah metode survey dengan pendekatan asosiatif, teknik pengumpulan data yang digunakan adalah studi kepustakaan dan studi lapangan dengan cara observasi, wawancara dan angket. Selanjutnya di uji secara analisis kuantitatif dengan menggunakan teknik korelasi product momen dan dilanjutkan dengan pengujian regresi linier sederhana dalam SPSS (Statistical Product and Solution Service). Berdasarkan hasil penelitian yang diperoleh menunjukan : Pengaruh Iklim Organisasi Dinas Perhubungan Kota Tangerang sebesar 75\%, sedangakan Produktivitas Kerja pegawai Dinas Perhubungan Kota Tangerang sebesar 76\%. Hubungan Pengaruh Iklim Organisasi terhadap Produktivitas Kerja Pegawai Pada Dinas Perhubungan Kota Tangerang 95,6\% sehingga nilai korelasi tersebut memiliki tingkat hubungan yang kuat antara variabel Pengaruh Iklim Organisasi Terhadap Produktivitas Kerja Pegawai Pada Dinas Perhubungan Kota Tangerang. Yang ditunjuka dengan dengan $r=0,956$. Jika diinterprestasikan menurut Sugiyono (2017:231) bahwa : "interval koefisien korelasi memiliki tingkat hubungan kuat, atau nilai-nilai ini terletak pada posisi interval koefisien antara $0,80-1,000$ " Koefisien determinasi $\left(\mathrm{r}^{2}\right)=0,978^{2}=0,956$ Peneiti memberikan pengaruh kepada variabel kepuasan kerja karyawan sebesar 95,6\% dan sisanya 4,4\% dipengaruhi oleh faktor lain. Hal ini ditunjukan oleh hasil pengujian menggunakan SPSS (Statistical Product and Solution Service) yang menunjukan tingkat signifikan 0,000 yang berarti lebih kecil dari 0,5 dan thitung sebesar 42,936 yang lebih besar dari t tabel 1,662 dalam keadaan ini menunjukan bahwa Ho ditolak dan Ha diterima, jadi hipotesis yang peneliti ajukan terbukti kebenarannya, artinya ada pengaruh secara signifikan dari Pengaruh Iklim Organisasi Terhadap Produktivitas Kerja Pegawai Pada Dinas Perhubungan Kota Tangerang Implikasi yang peneliti ajukan pada Dinas Perhubungan Kota Tangerang yaitu untuk mengantisipasi masalah Produktivitas Kerja Pegawai Pada Dinas Perhubungan Kota Tangerang maka dapat ditingkatkan melalui Pengaruh Iklim Organisasi Dinas Perhubungan Kota Tangerang.
\end{abstract}

\section{A. PENDAHULUAN}

Kelangsungan hidup dan keberhasilan suatu organisasi, disamping tergantung pada peran dan kualitas manusia, tetapi juga memerlukan dukungan alat-alat dan sumber daya lainnya. Peran dan kualitas manusia-manusia yang berada di dalam organisasi baik secara individu maupun kelompok merupakan sebagai faktor penting dalam pencapaian tujuan organisasi, maka setiap manusia yang bekerja sebagai pegawai dalam organisasi haruslah diberikan pelatihan-pelatihan dalam rangka meningkatkan sumber daya manusia. Namun demikian, disamping meningkatkan sumber daya manusia dari para pegawai, dapat perlu juga di lakukan pembinaan hubungan kerjasama diantara pegawai tersebut secara konfrehensif. Karena, dengan demikian akan terciptanya iklim organisasi yang baik. Terkait dengan unsur pelaksanaan, organisasi pada Dinas Perhubungan Kota Tangerang beserta seluruh anggotanya merupakan bagian organisasi dalam 
lingkungan pemerintahan. Pada Dinas Perhubungan Kota Tangerang, mempunyai peranan yang penting dalam penyelenggaraan tugas pemerintahan dan pembangunan diwilayah instansi Pemerintahan Kota Tangerang. Maka dari itu, diperlukan mengenai iklim organisasi dan berupaya meningkatkan produktivitas kerja pegawai dalam melaksanakan tugas yang efektif dan efisien kepada masyarakat.

Dinas Perhubungan Kota Tangerang selalu berusaha dapat memberikan pelayanan yang baik kepada masyarakat dalam meningkatkan produktivitas kerja pegawai, melalui iklim organisasi agar tujuan dari Dinas Perhubungan Kota Tangerang dapat tercapai. Dengan demikian sangatlah penting bagi seorang pegawai dalam berusaha untuk meningkatkan produktivitas kerja pegawai agar organisasi atau instansi pemerintahan dapat berkembang jauh lebih baik.

Namun hasil pengamatan menunjukkan adanya permasalahan yang dihadapi terkait dengan produktivitas kerja para pegawai. Hal ini dapat dilihat dari :

1. Masih kurangnya dukungan yang diberikan oleh pimpinan dalam memberikan arahan dalam bekerja, yang mengakibatkan pegawai merasa kesulitan dalam menyelesaikan tugasnya.

2. Belum maksimalnya latar belakang pendidikan dan pengalaman kerja sehingga, pegawai tersebut tidak dapat merealisasikan rencana kerja dalam meningkatkan hasil kerja.

3. Belum maksimalnya rasa tanggung jawab pegawai saat bekerja sehingga, tugas yang diberikan tidak terlaksana dengan tepat waktu.

Peneliti dapat merumuskan masalah penelitian yang merupakan research question (pertanyaan penelitian) sebagai berikut : "Bagaimanakah pengaruh iklim organisasi terhadap produktivitas kerja pegawai pada Dinas Kota Tangerang”.

\section{B.KAJIAN PUSTAKA, KERANGKA PEMIKIRAN, DAN HIPOTESIS}

\section{Iklim Organisasi}

Davis dalam Dharma (2001:21) mendefinisikan : "Iklim organisasi adalah lingkungan manusia dimana para pegawai organisasi melakukan pekerjaannya". Iklim organisasi tidak dapat dilihat atau disentuh tetapi iklim ada seperti udara dalam suatu ruangan mengitari dan mempengaruhi segala hal yang terjadi dalam suatu organisasi”. Selain itu iklim organisasi juga mempengaruhi sikap dan perilaku para pegawai didalam suatu organisasi. Yaitu seperti yang dijelaskan Taguiri dan Litwin dalam Soetopo (2012:141) mengartikan : "Iklim organisasi adalah suatu kualitas lingkungan internal organisasi yang dialami oleh anggotanya, mempengaruhi perilakunya, dan dapat dideskripsikan dengan nilai-nilai karateristik organisasi”.

Dari beberapa pengertian para ahli tentang iklim organisasi maka dapat disimpulkan bahwa iklim organisasi adalah suasana atau keadaan kerja yang dimana para pegawainya menjalin suatu hubungan kerjasama dalam suatu kelompok dengan ditandai oleh rasa keakraban yang terjalin guna tercapainya tujuan organisasi.

\section{Dimensi Iklim Organisasi}

Stringer dalam Wirawan (2008:131) menjelaskan bahwa : "Karakteristik atau dimensi iklim organisasi mempengaruhi motivasi anggota organisasi untuk berperilaku tertentu". Oleh karena itu, iklim organisasi dapat dilukiskan dan diukur dalam pengertian dimensi tersebut. Ia mengatakan bahwa untuk mengukur iklim organisasi terdapat enam dimensi yang diperlukan. Seperti sebagai berikut : 


\section{Strukur}

Struktur (structure) organisasi merefleksikan perasaan diorganisasi secara baik dan mempeunyai peran dan tanggung jawab yang jelas dalam lingkungan organisasi. Struktur tinggi jika anggota organisasi merasa pekerjaan mereka didefinisikan secara baik.

2. Standar-standar

Standar-standar (standards) dalam suatu organisasi mengukur perasaan tekanan untuk meningkatkan kinerja dan derajat kebanggan yang dimiliki oleh anggota organisasi dalam melakukan pekerjaan dengan baik.

3. Tanggung jawab

Tanggung jawab merefleksikan perasaan karyawan bahwa mereka menjadi "bos diri sendiri" dan tidak memerlukan keputusannya dilegitimasi oleh anggota organisasi lainnya.

4. Penghargaan

Penghargaan mengidentifikasi bahwa anggota organisasi merasa dihargai jika mereka dapat menyelesaikan tugas secara baik. Penghargaan merupakan ukuran penghargaan dihadapkan dengan kritik dan hukuman atas penyelesaian pekerjaan.

5. Dukungan

Dukungan (support) merefleksikan perasaan percaya dan saling mendukung yang terus berlangsung diantara anggota kelompok kerja. Dukungan tinggi jika anggota organisasi merasa bahwa mereka bagian tim yang berfungsi dengan baik dan merasa memperoleh bantuan dari atasannya, jika mengalami kesulitan dalam menjalankan tugas.

6. Komitmen

Komitmen (commitment) merefleksikan perasaan bangga anggota terhadap organisasinya dan derajat keloyalan terhadap pencapaian tujuan organisasi. Perasaan komitmen kuat berasosiasi dengan loyalitas personal. Level rendah komitmen artinya karyawan merasa apatis terhadap organisasi dan tujuannya.

\section{Produktivitas}

Greenberg dalam Sutrisno (2013:12) menjelaskan produktivitas sebagai perbandingan antara totalitas pengeluaran pada waktu tertentu dibagi totalitas masukan selama periode tersebut. Dan seperti yang dijelaskan produktivitas yang baik itu selalu ingin melakukan perbaikan dalam bentuk hasil kerja dalam pekerjaannya. Tohardi dalam Sutrisno (2013:99) menjelaskan bahwa: Produktivitas kerja merupakan sikap mental. Sikap mental yang selalu mencari perbaikan terhadap apa yang telah ada. Suatu keyakinan bahwa seseorang dapat melakukan pekerjaan lebih baik dari hari ini dari pada hari kemarin dan hari esok lebih baik hari ini.

\section{Faktor-faktor Yang Mempengaruhi Produktivitas}

Sutrisno (2013:210), mengatakan bahwa faktor-faktor yang mempengaruhi produktivitas kerja dapat disimpulkan menjadi dua golongan, yaitu:

1. Faktor yang ada pada diri individu, yaitu umur, temperamental, keadaan fisik individu, kelemahan dan motivasi.

2. Faktor yang ada di luar individu, yaitu kondisi fisik seperti suara, penerangan, waktu, istirahat, lama kerja, upah, bentuk organisasi, lingkungan sosial dan keluarga.

Kemudian menurut Siagian (2003:105) faktor-faktor yang mempengaruhi produktifitas kerja meliputi Pendidikan, Pelatihan, Penilaian prestasi kerja, Sistem Imbalan, Motivasi dan Kepuasan Kerja. Untuk mendukung pendapat Siagian, Wana Nusa dalam Sumarsono (2003:87) 
mengungkapkan bahwa faktor yang mempengaruhi produktivitas kerja meliputi Pendidikan, Ketrampilan, Disiplin, Motivasi, Sikap dan Etika Kerja, Gizi dan Kesehatan, Tingkat Penghasilan, Jaminan Lingkungan dan Iklim Kerja, Hubungan Kerja, Teknologi, Sarana Fasilitas, Manajemen dan Kesempatan Berprestasi.

Dengan demikian, jika karyawan diperlakukan secara baik oleh atasan atau adanya hubungan antar pegawai yang baik, maka pegawai tersebut akan berpartisipasi dengan baik pula dalam proses produksi, sehingga akan berpengaruh pada tingkat produktivitas kerja pegawai.

\section{Indikator-indikator Produktivitas}

Untuk mengukur dalam peningkatan produktivitas kerja pegawai diperlukan indikator produktivitas. Seperti yang dijelaskan oleh Sutrisno (2013:211) bahwa produktivitas merupakan suatu hal sangat penting bagi para pegawai yang ada diperusahaan. Dengan adanya produktivitas kerja diharapkan pekerjaan akan terlaksana secara efektif dan efisien, sehingga ini semua akhirnya sangat diperlukan dalam pencapaian tujuan yang sudah diterapkan. Untuk mengukur produktivitas kerja, diperlukan suatu indikator, yaitu sebagai berikut :

a. Kemampuan

b. Meningkatkan hasil yang dicapai

c. Semangat kerja

d. Pengembangan diri

e. Mutu

f. Efisiensi

\section{METODOLOGI PENELITIAN}

\section{Metode Penelitian}

Sugiyono (2014 : 2) mengemukakan : "Metode Penelitian pada dasarnya merupakan cara ilmiah untuk mendapatkan data dengan tujuan dan kegunaan tetentu secara rasional, empiris, dan sistematis". Pendekatan rasional memberikan kerangka berpikir yang logis dan masuk akal. Pendekatan empiris memberikan kerangka pengujian dalam memastikan suatu kebenaran yang sesuai fakta dilapangan, sedangkan pendekatan yang sistematis memberikan kerangka penelitian dengan menggunakan langkah-langkah tertentu yang bersifat logis.

Metode penelitian yang digunakan adalah metode kuantitaif. Menurut Sugiyono (2014 : 8) "Metode penelitian kuantitaif dapat diartikan sebagai metode penelitian yang berlandaskan pada filsafat positivisme, digunakan untuk meneliti pada populasi atau sampel tertentu, pengumpulan data menggunakan instrument penelitian, analisis data bersifat kuantitatif/statistik, dengan tujuan untuk menguji hipotesis yang telah ditetapkan". Dengan menggambarkan metode asosiatif kuantitatif, dalam hal ini penelitian bertujuan untuk mengetahui hubungan antara dua variabel atau lebih. Menurut Sugiyono Dalam buku Metode Penelitian Administrasi menjelaskan bahwa "Penelitian Asosiatif merupakan penelitian yang bertujuan untuk mengetahui hubungan dua variabel atau lebih.

\section{Populasi dan Sampel}

Populasi dalam penelitian ini adalah pegawai pada Dinas Perhubungan Kota Tangerang dengan jumlah pegawai berdasarkan golongan dan tingkat pendidikan adalah 109 Orang. Ditinjau dari 
banyaknya anggota populasi pada Dinas Perhubungan Tangerang, maka dalam kaitan ini peneliti menggunakan teknik pengambilan sampel, yaitu dengan teknik proportionate stratified random sampling. Menurut Sugiyono (2014 : 82) bahwa "proportionate stratified random sampling digunakan bila populasi mempunyai anggota/unsur yang tidak homogen dan berstrata secara proporsional".

Adapun perhitungan besarnya sampel sebagai berikut :

$$
\begin{aligned}
& \mathrm{n}=\frac{109}{1+109(0,05)^{2}} \\
& \mathrm{n}=85,658 \text { atau } 86
\end{aligned}
$$

Jadi, jumlah sampel yang digunakan dalam penelitian ini sebanyak 86 dari 109 populasi.

\title{
Instrumen Penelitian
}

Didalam melakukan penelitian terdapat dua hal utama yang mempengaruhi kualitas data hasil penelitian, yaitu kualitas instrumen penelitian dan kualitas pengumpulan data. Instrumeninstrumen yang digunakan adalah bagai mana sumber data, teknik pengumpulan data. Semua itu mempengaruhi kualitas hasil penelitian.

\section{Jenis dan Sumber Data}

Dalam melakukan penelitian ini, penulis mengambil jenis sumber data sebagai berikut :

a. Sumber primer. Sumber data primer dalam penelitian ini berasal dari angket yang disebar kepada responden, responden adalah pegawai Dinas Perhubungan Kota Tangerang.

b. Sumber Sekunder. Sugiyono (2016 : 225) menyatakan : "Sumber sekunder merupakan sumber yang tidak langsung memberikan data kepada pengumpul data misalnya lewat orang lain atau dokumen".

\section{Teknik Pengumpulan Data}

a. Studi Kepustakaan, yaitu mempelajari data dan teori melalui literatur kepustakaan, data dan teori-teori yang diperoleh bersumber dari buku-buku, dokumen serta pedoman-pedoman umum lainnya yang erat dengan permasalahan yang dikaji (Gulo, $2006: 12$ )

b. Studi lapangan meliputi :

1) Obsevasi

2) Wawancara

3) Kuesioner (Angket)

\section{HASIL PENELITIAN DAN PEMBAHASAN}

\author{
Hasil Uji Validitas, Reliabilitas dan Normalitas Data
}

1. Uji Validitas dan Reliabilitas Variabel X (Iklim Organisasi) 


\section{Hasil Untuk Hasil Validitas Iklim Organisasi (X)}

\begin{tabular}{|c|c|c|c|c|c|}
\hline \multicolumn{6}{|c|}{ Item-Total Statistics } \\
\hline & $\begin{array}{l}\text { Scale Mean if } \\
\text { Item Deleted }\end{array}$ & $\begin{array}{c}\text { Scale Variance if } \\
\text { Item Deleted }\end{array}$ & $\begin{array}{l}\text { Corrected Item- } \\
\text { Total Correlation }\end{array}$ & $\begin{array}{c}\text { Squared Multiple } \\
\text { Correlation }\end{array}$ & $\begin{array}{l}\text { Cronbach's } \\
\text { Alpha if Item } \\
\text { Deleted }\end{array}$ \\
\hline VAR00001 & 18,7093 & 8,820 & ,802 &, 947 & ,872 \\
\hline VAR00002 & 18,8023 & 9,337 & ,775 & ,959 & ,876 \\
\hline VAR00003 & 18,7093 & 9,385 & ,826 & ,881 & ,869 \\
\hline VAR00004 & 18,8023 & 10,113 & ,762 & ,825 & ,882 \\
\hline VAR00005 & 18,9070 & 8,532 & ,785 & ,919 & ,876 \\
\hline VAR00006 & 19,0930 & 10,932 & ,471 & ,684 & ,917 \\
\hline
\end{tabular}

Jika $\mathrm{r}_{\text {hitung }}>\mathrm{r}_{\text {tabel, }}$, maka pertanyaan tersebut dinyatakan valid, seperti tertera pada tabel berikut :

\section{Perbandingan Antara R Hitung Dengan R Tabel Variabel Iklim Organisasi (X)}

\begin{tabular}{|c|c|c|c|c|}
\hline No Pertanyaan & $\mathrm{r}$ hitung & $\mathrm{r}$ tabel & Hasil & Keterangan \\
\hline 1 & 0,802 & 0,212 & $\mathrm{r}_{\text {hitung }}>\mathrm{r}_{\text {tabel }}$ & Valid \\
\hline 2 & 0,775 & 0,212 & $\mathrm{r}_{\text {hitung }}>\mathrm{r}_{\text {tabel }}$ & Valid \\
\hline 3 & 0,826 & 0,212 & $\mathrm{r}_{\text {hitung }}>\mathrm{r}_{\text {tabel }}$ & Valid \\
\hline 4 & 0,762 & 0,212 & $\mathrm{r}_{\text {hitung }}>\mathrm{r}_{\text {tabel }}$ & Valid \\
\hline 5 & 0,785 & 0,212 & $\mathrm{r}_{\text {hitung }}>\mathrm{r}_{\text {tabel }}$ & Valid \\
\hline 6 & 0,471 & 0,212 & $\mathrm{r}_{\text {hitung }}>\mathrm{r}_{\text {tabel }}$ & Valid \\
\hline
\end{tabular}

Berdasarkan data pada tabel di atas. Stelah dilakukan uji validitas menunjukkan total nilai-nilai $r$ hitung $>\mathrm{r}$ tabel $(0,197) . \mathrm{r}$ tabel dapat dilihat pada $\alpha 0,05$ dengan derajat bebas 86-2 sehingga akan dapat ( $\mathrm{r}$ tabel 84 : 0,212). Hal ini membuktikan bahwa butiran-butiran instrumen variabel iklim organisasi (X) layak digunakan untuk penelitian lebih lanjut.

\section{Uji Reliabilitas Variabel Iklim Organisasi}

Reliability Statistics

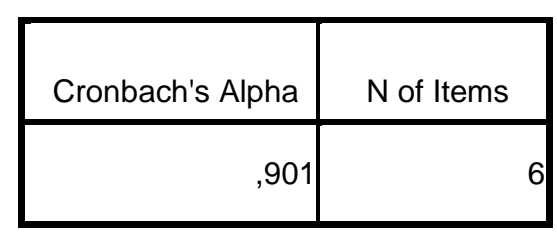

Jika Cronbach's Alpha positif dan lebih besar dari r tabel maka, reliable. Hasil uji Reliabilitas Kuesioner Variabel Iklim Organisasi menyatakan: Cronbach's Alpha $>r_{\text {tabel }}$ 0,901 > 0, 212 sehingga kuesioner tersebut bersifat valid. Oleh karena itu kuesioner dinyatakan valid dan reliabel. 


\section{Uji Validitas dan Reliabilitas Variabel Produktivitas Kerja (Y)}

\section{Hasil SPSS Untuk Validitas Produktivitas Kerja (Y)}

\begin{tabular}{|l|r|r|r|r|r|}
\hline & $\begin{array}{c}\text { Scale Mean if } \\
\text { Item Deleted }\end{array}$ & $\begin{array}{c}\text { Scale Variance if } \\
\text { Item Deleted }\end{array}$ & $\begin{array}{c}\text { Corrected Item- } \\
\text { Total Correlation }\end{array}$ & $\begin{array}{c}\text { Squared Multiple } \\
\text { Correlation }\end{array}$ & $\begin{array}{c}\text { Cronbach's } \\
\text { Alpha if Item } \\
\text { Deleted }\end{array}$ \\
\hline VAR00001 & 19,0930 & 10,932 &, 916 &., 917 \\
VAR00002 & 19,1860 & 11,565 &, 883 &, 922 \\
VAR00003 & 19,0930 & 11,874 &, 878 &, 924 \\
VAR00004 & 19,1860 & 13,118 &, 709 &, 943 \\
VAR00005 & 19,2907 & 11,667 &, 679 &. \\
VAR00006 & 19,0930 & 10,932 &, 916 & .951 \\
\hline
\end{tabular}

Jika $\mathrm{r}_{\text {hitung }}>\mathrm{r}_{\text {tabel}}$, maka pertanyaan tersebut dinyatakan valid, seperti tertera pada tabel berikut :

Perbandingan Antara R Hitung Dengan R Tabel Variabel Produktivitas Kerja (Y)

\begin{tabular}{|c|c|c|c|c|}
\hline $\begin{array}{c}\text { No. } \\
\text { Pertanyaan }\end{array}$ & $\mathrm{r}$ hitung & $\mathrm{r}$ tabel & Hasil & Keterangan \\
\hline 1 & 0,916 & 0,212 & $\mathrm{r}_{\text {hitung }}>\mathrm{r}_{\text {tabel }}$ & Valid \\
\hline 2 & 0,883 & 0,212 & $\mathrm{r}_{\text {hitung }}>\mathrm{r}_{\text {tabel }}$ & Valid \\
\hline 3 & 0,878 & 0,212 & $\mathrm{r}_{\text {hitung }}>\mathrm{r}_{\text {tabel }}$ & Valid \\
\hline 4 & 0,709 & 0,212 & $\mathrm{r}_{\text {hitung }}>\mathrm{r}_{\text {tabel }}$ & Valid \\
\hline 5 & 0,679 & 0,212 & $\mathrm{r}_{\text {hitung }}>\mathrm{r}_{\text {tabel }}$ & Valid \\
\hline 6 & 0,916 & 0,212 & $\mathrm{r}_{\text {hitung }}>\mathrm{r}_{\text {tabel }}$ & Valid \\
\hline
\end{tabular}

Berdasarkan data pada tabel 4.5 diatas. Setelah dilakukan uji validitas menunjukkan total nilainilai $r_{\text {hitung }}>r_{\text {tabel }}(0,212) . r$ tabel dapat dilihat pada $\alpha 0,05$ dengan derajat bebas 86-2 sehingga akan dapat ( $\mathrm{r}$ tabel $84: 0,212$ ). Hal ini membuktikan bahwa butiran-butiran instrumen variabel Produktivitas Kerja (Y) layak digunakan untuk penelitian lebih lanjut.

\section{Uji Reliabilitas Variabel Produktivitas Kerja}

\section{Hasil SPSS Untuk Reliability Statistics Variabel Produktivitas Kerja}

\begin{tabular}{|r|r|}
\multicolumn{2}{c}{ Reliability Statistics } \\
\hline Cronbach's Alpha & N of Items \\
\hline, 940 & 6 \\
\hline
\end{tabular}

Jika Cronbach's Alpha positif dan lebih besar dari r tabel maka reliabel. Hasil uji Reliabilitas Kuesioner Variabel Produktivitas Kerja menyatakan : Cronbach's Alpha $>r_{\text {tabel }}$ 0,940 > 0, 212 sehingga kuesioner tersebut bersifat valid. Oleh karena itu kuesioner dinyatakan valid dan reliabel.

\section{Iklim Organisasi Pada Dinas Perhubungan Kota Tangerang.}

Hasil penelitian nilai pelaksanaan fungsi iklim organisasi berdasarkan data yang terkumpul, yaitu total skor tertinggi (maximum) adalah 29 dan jumlah responden pada penelitian ini 
sebanyak 86 orang, maka skor tertinggi yang merupakan skor kriteriun adalah $86 \times 6 \times 5=2580$ yang merupakan skor kriterium. Sedangkan jumlah skor total adalah variabel (X) iklim organisasi berdasarkan data yang diperoleh dari $\sum X$ adalah 1944. Dengan demikian, iklim organisasi yaitu $1944: 2580=0,753$ dan dibulatkan menjadi 0,75 atau $75 \%$ artinya data tersebut baik yang menunjukkan bahwa iklim organisasi pada Dinas Perhubugan Kota Tangerang.

\section{Produktivitas Kerja Pada Dinas Perhubungan Kota Tangerang}

Hasil penelitian nilai pelaksanaan fungsi Produktivitas Kerja berdasarkan data yang terkumpul, yaitu total skor tertinggi (maximum) adalah 30 dan jumlah responden pada penelitian ini sebanyak 86 orang, maka skor tertinggi yang merupakan skor kriteriun adalah 86 x 6 x $5=2580$ yang merupakan skor kriterium. Sedangkan jumlah skor total adalah variabel (Y) Produktivitas Kerja berdasarkan data yang diperoleh dari $\sum Y$ adalah 1977. Dengan demikian, iklim organisasi yaitu $1977: 2580=0,766$ dan dibulatkan menjadi 0,76 atau $76 \%$ artinya data tersebut baik yang menunjukkan bahwa Produktivitas Kerja pada Dinas Perhubugan Kota Tangerang.

\section{Pengaruh Iklim Organisasi Terhadap Produktivitas Kerja Pegawai Pada Dinas Perhubungan Kota Tangerang}

\begin{tabular}{|ll|r|r|}
\hline \multicolumn{2}{|c|}{ Correlations } \\
\hline VAR00001 & VAR00001 & VAR00002 \\
& Pearson Correlation & 1 &, $978^{* *}$ \\
& Sig. (2-tailed) & &, 000 \\
& $\mathrm{~N}$ & 86 & 86 \\
\hline VAR00002 & Pearson Correlation &, $978^{* *}$ & 1 \\
& Sig. (2-tailed) &, 000 & \\
& $\mathrm{~N}$ & 86 & 86 \\
\hline$*$. Correlation is significant at the 0.01 level (2-tailed).
\end{tabular}

Berdasarkan data pada tabel hasil analisis koefisien korelasi product moment, ada korelasi positif sebesar 0,978 antara iklim organisasi terhadap Produktivitas Kerja pegawai. Hal ini berarti semakin besar nilai iklim organisasi, semakin besar pula nilai Produktivitas Kerja pegawai. Koefisien korelasi tersebut jika berpedoman pada tabel interprestasi korelasi sebesar 0,978 memiliki tingkat hubungan sangat kuat karena berada pada posisi interval koefisien $0,80-1,000$.

\section{Uji Koefisien Determinasi}

\begin{tabular}{l|r|r|r|r|}
\hline Model & $\mathrm{R}$ & $\mathrm{R}$ Square & $\begin{array}{c}\text { Adjusted R } \\
\text { Square }\end{array}$ & $\begin{array}{c}\text { Std. Error of the } \\
\text { Estimate }\end{array}$ \\
\hline 1 &, 978 &, 956 &, 956 &, 76991 \\
\hline
\end{tabular}
a. Predictors: (Constant), VAR00002
b. Dependent Variable: VAR00001

Berdasarkan data pada tabel di atas dapat diketahui bahwa determinasi dari koefisien korelasi diperoleh skor 95,6\%, ini membuktikan bahwa pengaruh iklim organisasi memberikan konstribusi terhadap Produktivitas Kerja sebesar 95,6\% dan sebesar 4,4\% dipengaruhi oleh faktor lain. 
Uji Hipotesis (t hitung)

\begin{tabular}{|c|c|c|c|c|c|c|}
\hline \multicolumn{7}{|c|}{ Coefficients $^{a}$} \\
\hline \multirow{2}{*}{\multicolumn{2}{|c|}{ Model }} & \multicolumn{2}{|c|}{ Unstandardized Coefficients } & $\begin{array}{c}\text { Standardized } \\
\text { Coefficients }\end{array}$ & \multirow[b]{2}{*}{$\mathrm{t}$} & \multirow[b]{2}{*}{ Sig. } \\
\hline & & $\mathrm{B}$ & Std. Error & Beta & & \\
\hline \multirow[t]{2}{*}{1} & (Constant) & 2,388 & ,478 & & 4,995 & ,000 \\
\hline & VAR00002 & ,879 & ,020 & ,978 & 42,936 &, 000 \\
\hline
\end{tabular}

a. Dependent Variable: VAR00001

Berdasarkan hasil koefisien korelasi antara iklim organisasi terhadap Produktivitas Kerja pegawai sebesar 0,879 dan didapat t hitung sebesar 42,936 maka hipotesis dirumuskan sebagai berikut :

- Apabila sig <0,05, maka ditolak dan Ha diterima.

- Apabila sig > 0,05, maka Ho diterima dan Ha ditolak (tidak ada pengaruh yang signifikan). Atau :

- Apabila thitung $>t$ tabel, maka Ho ditolak dan Ha diterima.

- Apabila $t_{\text {hitung }}<\mathrm{t}_{\text {tabel }}$, maka Ho diterima dan Ha ditolak (tidak ada pengaruh yang signifikan).

Data pada tabel diatas diketahui nilai $\mathrm{t}_{\text {hitung }}$ sebesar 42,936 sedangkan nilai $\mathrm{t}_{\text {tabel }}$ dalam ketentuan 1,662. Dengan demikian, sesuai dalam hitungan hipotesis statistik jika $t$ hitung $(42,935)>t$ tabel $(1,662)$, maka Ho ditolak dan Ha diterima. Artinya hipotesis yang peneliti kemukakan : "Terdapat Pengaruh Positif Antara Iklim Organisasi Terhadap Produktivitas Kerja Pegawai Pada Dinas Perhubungan Kota Tangerang” berikut kebenarannya.

\section{Uji Signifikan Koefisien Korelasi Uji Dua Pihak}

\section{Daerah penolakan Ho Daerah penolakan Ho}

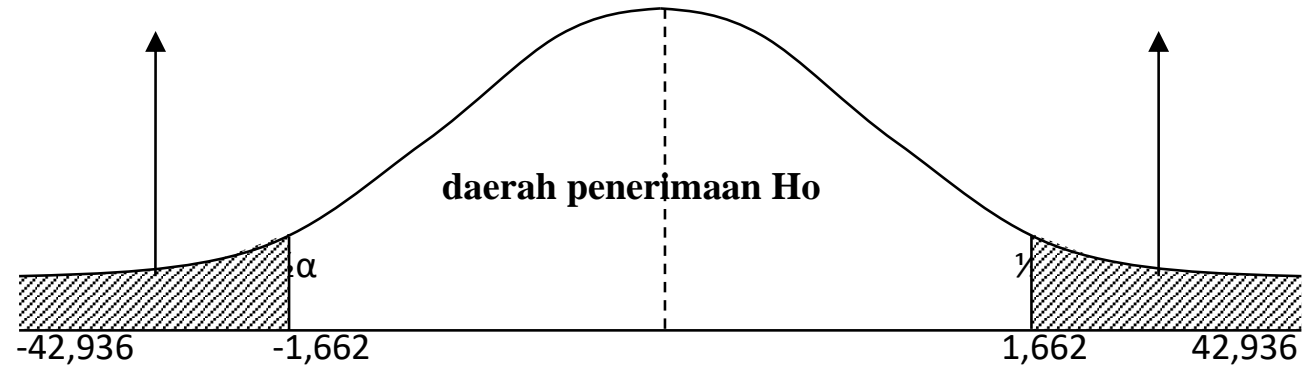

\section{Analisis Regresi Liner}

\begin{tabular}{|c|c|c|c|c|c|c|}
\hline \multicolumn{7}{|c|}{ Coefficients $^{a}$} \\
\hline \multirow{2}{*}{\multicolumn{2}{|c|}{ Model }} & \multicolumn{2}{|c|}{ Unstandardized Coefficients } & $\begin{array}{c}\text { Standardized } \\
\text { Coefficients }\end{array}$ & \multirow[b]{2}{*}{$\mathrm{t}$} & \multirow[b]{2}{*}{ Sig. } \\
\hline & & $\mathrm{B}$ & Std. Error & Beta & & \\
\hline & (Constant) & 2,388 & ,478 & & 4,995 &, 000 \\
\hline & VAR00004 & ,879 & ,020 & ,978 & 42,936 &, 000 \\
\hline
\end{tabular}

a. Dependent Variable: VAR00003 
Berdasarkan tabel koefisien korelasi regresi, maka persamaan regresi linier sederhana adalah sebagai berikut :

$$
\begin{aligned}
\hat{Y} & =a+b X \\
& =-2,3888+0,879 X
\end{aligned}
$$

Persamaan regresi linier sederhana yang diketahui digunakan untuk melakukan predeksi sebagaimana individu dalam variabel iklim organisasi akan menjadi peningkatan bila individu dalam variabel efektivitas ditetapkan. Jadi bila iklim organisasi ditingkatkan sebesar 1 point, maka Produktivitas Kerja pegawai akan baik menjadi :

$\hat{\mathrm{Y}}=-2,388(0,879 \times 1)$

$\hat{\mathrm{Y}}=-2,388+0,879$

$\hat{\mathrm{Y}}=3.267$

Diperkirakan Produktivitas kerja akan naik sebesar 3.267 jika kualitas iklim organisasi berubah sebesar 1 point atau Produktivitas Kerja pegawai akan naik bila iklim organisasi lebih ditingkatkan. Hal ini membuktikan bahwa variabel iklim organisasi (X) searah terhadap naiknya dan turunnya variabel Produktivitas Kerja pegawai (Y)

\section{Hambatan-hambatan Yang Dihadapi Dalam Iklim Organisasi Terhadap Produktivitas Kerja Pegawai Pada Dinas Perhubungan Kota Tangerang dan Upaya-upaya Yang Dilakukan Untuk Mengetasinya}

Berdasarkan hasil penelitian menunjukan bahwa hambatan-hambatan yang dihadapi dalam iklim organisasi dengan Produktivitas Kerja pegawai untuk mencapai hasil yang kurang maksimal pada Dinas Perhubungan Kota Tangerang adalah sebagai berikut :

1. Kurangnya pengawasan pemimpin terhadap para pegawai, hal ini terlihat masih terdapat pegawai yang berbincang-bincang dengan rekan sekerjanya pada saat jam kerja sehingga pekerjaan menjadi terbengkalai sehingga terciptanya rasa tanggung jawab terhadap pekerjaanya sendiri.

2. Masih adanya persaingan antar pegawai dalam suatu organisasi untuk mencari kemenangan atau keuntungan masing-masing sehingga belum menimbulkan konflik internal yang akan merugikan organisasi akibatnya presentasi yang diraih pegawai tidak maksimal.

3. Kurangnya dorongan dan motivasi yang diberikan pimpinan kepada pegawai sehingga menimbulkan kinerja yang rendah.

Untuk mengatasi hambatan-hambatan sebagaimana dikemukakan diatas, maka upaya-upaya yang ditempuh untuk mengatasinya antara lain :

1. Meningkatkan pengawasan dari pimpinan kepada pegawai agar pegawai mampu memanfaatkan jam kerja dengan sebaik mungkin sehingga dapat meningkatkan rasa tanggung jawab yang tinggi.

2. Meningkatkan hubungan kekeluargaan dalam organisasi guna mempercepat persaudaraan dan tidak menimbulkan persaingan antar pegawai sehingga tercipta hubungan yang harmonis.

3. Meningkatkan peran atasan untuk memberikan motivasi seperti memberikan peenghargaan kepada para pegawai dan kesempatan rotasi pegawai guna memberikan semangat kerja pegawai. 


\section{E. KESIMPULAN DAN SARAN}

\section{Kesimpulan}

1. Hasil penelitian menunjukan bahwa iklim organisasi pada Dinas Perhubungan Kota Tangerang dalam kondisi baik, yaitu sebesar 0,75 atau dipersentasikan menjadi $75 \%$ dari kriteria yang ditetapkan.

2. Produktivitas kerja pegawai pada Dinas Perhubungan Kota Tangerang juga dalam kondisi baik, yaitu sebesar 0,76 atau dipersentasikan $76 \%$ dari kritria yang ditetapkan.

3. Hasil penelitian menunjukkan bahwa pengaruh iklim organisasi memberikan konstribusi terhadap Produktivitas Kerja sebesar 95,6\% dan sisanya sebesar 4,4\% dipengaruhi oleh faktor lain. yang tidak diteliti.

\section{Saran}

1. Sebaiknya adanya perhatian dari pimpinan terkait tanggung jawab para pegawai dalam menyelesaikan tugasnya. Dimana dengan adanya pengawasan terkait tugas yang diberikan apakah sudah terselesaikan atau belum.

2. Untuk meningkatkan iklim organisasi pada Dinas Perhubungan Kota tangerang, sebaiknya antara pegawai harus memiliki rasa kekeluargaan baik dan saling memberi dukungan antara pegawai baru maupun lama.

3. Sebaiknya pemimpin harus lebih jeli dalam memberikan penghargaan terhadap pegawai dengan memperhatikan siapa yang berprestasi dan tidak, sehingga dengan demikian akan adanya peningkatan sumber daya manusia yang baik tanpa adanya rasa iri dalam hati pegawai.

\section{DAFTAR PUSTAKA}

Akdon. 2011. Strategi Manajemen. Bandung : Alfabeta.

Ali, Faried. 2005. Teori dan Konsep Administrasi. Jakarta : PT RajaGrafindo Persada.

Cahayani, Ati. 2003. Dasar-Dasar Organisasi dan Manajemen. Jakarta : PT Grasindo.

Darodjat, Tugabus Achamd. 2015. Pentingnya Budaya Kerja Tinggi dan Kuat. Cetakan Kesatu, Bandung : PT. Refika Aditama.

Davis, Keith and Newstrom. 2001. Perilaku Dalam Organisasi. Edisi ke tujuh. Jilid satu. Jakarta : Erlangga.

Kamuli, Sukarman. 2012. "Pengaruh Iklim Organisasi Terhadap Produktivitas Kerja Pegawai Di Sekretariat Daerah Kota Gorontalo”. Jurnal Inovasi. Vol. 5, No. 1 : 701-706.

Nawawi, Zaidan. 2015. Manajemen Pemerintahan. Jakarta : PT RajaGrafindo Persada.

Pamudji. 1986. Ekologi Administrasi Negara. Jakarta : Bina Aksara.

Robbins, P. Stephen. 2014. Perilaku Organisasi. Cetakan ke dua belas. Jakarta : Salemba Empat. 
Siagian, P. Sondang. 2004. Manajemen Sumber Daya Manusia. Jakarta: Bumi Aksara.

Soetopo, Hendyat. 2012. Perilaku Organisasi. Cetakan ke dua. Bandung : PT Remaja Rosdakarya.

Sugiyono. 2012. Statistik Untuk Penelitian. Bandung : CV. Alfabeta.

2014. Metode Penelitian Administrasi Dilengkapi dengan Metode R\&D. Bandung : CV. Alfabeta. .2016. Metode Penelitiaan Kuantitatif, kualitatif, dan R\&D. Bandung :CV. Alfabeta.

Sutrisno, Edy. 2013. Budaya Organisasi. Cetakan ke tiga. Jakarta : Kencana Prenada Media Group.

Syafiie, Inu Kencana. 2015. Sistem Administrasi Negara Republik Indonesia (SANKRI). Jakarta : Bumi Askara.

Wirawan. 2008. Budaya dan Iklim Organisasi. Cetakan kedua. Jakarta : Salemba Empat.

\section{Dokumen}

Al-Qur'an Surat Al-Araf Ayat : 96 yang Berkaitan Tentang Iklim Organisasi. Bandung : Bahrul'uluum.

Al-Qur'an Surat Al-Hujurat Ayat : 13 yang Berkaitan Tentang Iklim Organisasi. Bandung : Bahrul'uluum.

Al-Qur'an Surat At-Taubah Ayat : 105 yang berkaitan Tentang Produktivitas Kerja. Bandung : Bahrul'uluum.

Hadist Riwayat Bukhari Abu Muhammad Mahmud bin Ahmad bin Musa bin Ahmad bin Husain Al ghitabi, yang berkaitan dengan Produktivitas Kerja. Umdatul Qori Syarhu Shohih Bukhari, juz 13, al-Maktabah asy-Syamilah, al ishdar

Thabrani, Al. 2005 Mu'jam al-Kabir : juz 6, Mauqi’u al-Islam Dalam Software Maktabah Syamilah.

Undang-Undang Republik Indonesia Nomor 30 Tahun 2014 Tentang Administrasi Pemerintahan.

Peraturan Walikota No. 70 Tahun 2016 tentang Kedudukan, Susunan Organisasi, Tugas dan Fungsi Serta Tata Kerja Dinas Perhubungan Kota Tangerang

Peraturan Walikota Tangerang Nomor 94 Tahun 2016 tentang pembentukan organisasi dan tata kerja unit pelaksanaan teknis dinas angkutan umum massal pada Dinas Perhubungan Kota Tangerang 